\title{
Comunicação
}

[Communication]

\section{Frequência de anticorpos anti-Toxoplasma gondii em suínos abatidos sem inspeção em Belém}

[Serologic diagnosis of Toxoplasma gondii in swines slaughtered without inspection in Northern Brazil]

\author{
J.A. Freitas ${ }^{1}$, J.P. Oliveira ${ }^{2}$, O.S. Ramos $^{3}$, M.M. Ishizuka ${ }^{4}$ \\ ${ }^{1}$ Instituto de Saúde e Produção Animal - UFRA - Belém, PA \\ ${ }^{2}$ Agência de Defesa Agropecuária do Pará - Belém, PA \\ ${ }^{3}$ Laboratório Nacional Agropecuário-PA - Belém, PA \\ ${ }^{4}$ Faculdade de Medicina Veterinária e Zootecnia - USP - São Paulo, SP
}

O Toxoplasma gondii é um protozoário coccídeo heteroxeno de ampla distribuição mundial e tem como hospedeiro intermediário os animais domésticos e silvestres, e o homem como hospedeiro acidental (Taylor e Webster, 1998; Rey, 2001).

O T. gondii determina no homem uma doença zoonótica, geralmente latente e associada ao contato com animais infectados, às suas excreções e à ingestão de carne crua ou mal cozida. Nos animais domésticos, causa também uma infecção latente e em ambos uma grave doença, que pode ser confundida com outras de sintomatologia semelhante e para a qual a pesquisa sorológica é o diagnóstico definitivo (Dubey, 1986, 1996; Bonametti et al., 1997; Dias e Freire, 2005). A infecção por T. gondii tem sido identificada nos animais domésticos em diferentes sistemas de criação, animais submetidos ao abate, alimentos e em graves ocorrências relacionadas à saúde coletiva (Vidotto et al., 1990; Barci et al., 1998; Silva e Langoni, 2000; Fialho e Araújo, 2003).

A frequência de anticorpos anti- $T$. gondii em suínos no Brasil é variável e tem sido levantada por meio de inquéritos sorológicos realizados em várias partes do país. O T. gondii ocorre independentemente de região, raça, tipo, aptidão e faixa etária (D’Angelino e Ishizuka, 1986; Guimarães et al., 1992; Barci et al., 1998; Garcia et al., 1999).
O abate clandestino de suínos ocorre em diversos locais na região metropolitana de Belém, PA, sem que ocorram medidas e ações de vigilância sanitária da carne, que é consumida por diferentes camadas socioeconômicas da população. Assim, o objetivo deste trabalho foi levantar a ocorrência de patógenos em suínos abatidos clandestinamente na região metropolitana de Belém. Para tal, foram coletadas 110 amostras de soros, aleatoriamente, em nove locais, que foram submetidas à hemaglutinação indireta, para detecção de anticorpos IgM e IgG anti-T. gondii (Camargo et al, 1986; Fialho e Araujo, 2002). Foi considerado positivo reação a partir da diluição 1:16.

Observou-se frequência de $50,0 \%$ de positivos (intervalo de confiança 40,7\% |... 59,3\%, 95\% de significância), com a maior frequência na diluição 1:256 e distribuição de frequências de $1,8 \%$ e $1,8 \%, 6,4 \%$ e $15,4 \%, 20,0 \%$ e $25,4 \%$, $17,3 \%$ e $7,3 \%$ e $4,5 \%$ e $0,0 \%$ para anticorpos IgM e IgG em cada um dos soros testados (Marascuillo, 1971), respectivamente, nas diluições 1:16, 1:64, 1:256, 1:1024 e 1:2048.

Frequências de anticorpos IgM e IgG anti- $T$. gondii inferiores às determinadas nesse inquérito foram observadas em suínos abatidos em Belo Horizonte-MG e em Porto Alegre-RS (Passos et al., 1984; Fialho e Araújo, 2003). D’Angelino e Ishizuka (1986), Vidotto et al. (1990) e Garcia et al. (1999) também determinaram frequências

Recebido em 29 de fevereiro de 2008

Aceito em 31 de agosto de 2009

E. mail: jaf.bel@terra.com.br 
mais baixas de anticorpos anti-T. gondii, em suínos em Pirassununga-SP, em suínos criados na região de Londrina-PR e em suínos criados no norte do Paraná.

Frequências de anticorpos anti- $T$. gondii inferiores foram, também, determinadas em reprodutores suínos no estado de São Paulo e em matrizes suínas na região de Goiânia-GO, (Barci et al., 1998). Frequência mais alta que a determinada neste inquérito foi observada em suínos da raça Piau no estado de Minas Gerais (Guimarães et al., 1992).

Conclui-se que a infecção toxoplásmica está presente entre os suínos abatidos clandestinamente na região metropolitana de Belém, com elevado risco sanitário para a saúde humana.

Palavras-chave: Toxoplasma gondii, suínos, abate clandestino, hemaglutinação indireta, vigilância sanitária

\section{ABSTRACT}

To survey the occurrence of $\operatorname{IgM}$ and $\operatorname{IgG}$ anti-T. gondii antibodies in pigs slaughtered without inspection, 110 serum samples from different localities were submitted to indirect hemaglutination test. A frequency of $50.0 \%$ (confidence interval $40.7 \% \quad|\ldots| 59.3 \%$, 95\% significance) of positive sera was detected, with a distribution of frequency of $1.83 \%$ and $1.83 \%, 6.36 \%$ and $15.45 \%, 20.0 \%$ and $25.4 \%$, $17.3 \%$ and $7.3 \%$, and $4.5 \%$ and $0.0 \%$ for $\operatorname{Ig} M$ and $\operatorname{IgG}$ antibodies, respectively in 1:16, 1:64, 1:256, 1:1024, and 1:2048 serum dilutions. The toxoplasmic infection was present among pigs in the city of Belém.

Keywords: Toxoplasma gondii, swine, non-inspected slaughtering, indirect hemaglutination test, sanitary surveillance

\section{REFERÊNCIAS BIBLIOGRÁFICAS}

BARCI, L.A.G.; BERSANO, J.G.; GUIMARÃES, A.C.S. et al. Frequência de anticorpos anti-Toxoplasma gondii em plantéis de suínos reprodutores no estado de São Paulo, Brasil. Arq. Inst. Biol. São Paulo, v.65, p.111$113,1998$.

BONAMETTI, A.M.; PASSOS, J.N.; SILVA, E.M.K. et al. Surto de toxoplasmose aguda transmitida através da ingestão de carne crua de gado ovino. Rev. Soc. Bras. Med. Trop., v.30, p.21-25, 1997.

CAMARGO, M.E.; FERREIRA, A.W.; ROCCA, A. et al. Um teste prático para a sorologia da toxoplasmose: o teste de hemaglutinação. Estudo comparativo com os testes de imunofluorescência e imunoenzimático de captura de Ig M. Rev. Bras. Patol. Clin., v.22, p.196-201, 1986.

D'ANGELINO, J.L.; ISHIZUKA, M.M. Toxoplasmose suína. 3. Avaliação da prevalência de infecção toxoplásmica em rebanhos suínos pela prova de imunofluorescência indireta e hemaglutinação. Bol. Of. Sanit. Panam., v.100, p.634-645, 1986.
DIAS, R.A.; FREIRE, R.L. Surtos de toxoplasmose em seres humanos e animais. Semina: Cienc. Agrar., v.26, p.239-248, 2005.

DUBEY, J.P. Strategies to reduce transmission of Toxoplasma gondii to animals and humans. Vet. Parasitol., v.64, p.65-70, 1996.

DUBEI, J.P. Toxoplasmosis. J. Am. Vet. Med. Assoc., v.189, p.166-170, 1986.

FIALHO, C.G.; ARAUJO, F.A.P. Comparação entre os testes de imunofluorescência indireta e hemaglutinação indireta para a detecção de anticorpos anti-Toxoplasma gondii em soros de suínos. Acta Sci. Vet., v.30, p.185-189, 2002.

FIALHO, C.G.; ARAUJO, F.A.P. Detecção de anticorpos para Toxoplasma gondii em soro de suínos criados e abatidos em frigoríficos da região da grande Porto Alegre-RS, Brasil. Ciênc. Rural, v.33, p.893-897, 2003.

GARCIA, J.L.; NAVARRO, I.T.; OGAWA, L. et al. Soroprevalência do Toxoplasma gondii em suínos, bovinos, ovinos e equinos e sua correlação com humanos, felinos e caninos, oriundos de propriedades rurais do norte do Paraná-Brasil. Cienc. Rural, v.29, p.91-97, 1999. 
GUIMARÃES, A.M.; RIBEIRO, M.F.B.; LIMA, J.D. et al. Frequência de anticorpos antiToxoplasma gondii em suínos da raça Piau. Arq. Bras. Med. Vet. Zootec., v.44, p.69-71, 1992.

MARASCUILLO, L.A. Stastitical methods for behavorial science research. New York: McGraw-Hill, 1971. 578p.

PASSOS, L.M.F.; LIMA, J.D.; FIGUEIREDO, B.L. Frequência de anticorpos anti-Toxoplasma gondii em suínos abatidos em Belo Horizonte, Minas Gerais. Arq. Bras. Med. Vet. Zootec., v.36, p.649-657, 1984.

REY, L. Toxoplasma gondii e toxoplasmose. In. REY, L. Parasitos e doenças parasitárias do homem nas Américas e África. 3.ed. Rio de Janeiro: Guanabara Koogan, 2001. p.321-334.

SILVA, A.V.; LANGONI, H. Alimentos de origem animal e a toxoplasmose humana. Rev. Hig. Alim., v.14, p.34-39, 2000.

TAYLOR, M.A.; WEBSTER, A. Recent advances in the diagnosis in livestock of Cryptosporidia, Toxoplasma gondii, Giardia and other protozoa of veterinary importance. Res. Vet. Sci., v.65, p.183-193, 1998.

VIDOTTO, O.; NAVARRO, I.T.; GIRALDI, N. et al. Estudos epidemiológicos da toxoplasmose em suínos da região de Londrina-PR. Semina: Cienc. Agrar., v.11, p.53-59, 1990. 